\title{
PANDANGAN AL-QUR'AN ATAS PERAN AYAH DALAM PROSES PERKEMBANGAN ANAK (KAJIAN TAFSIR TEMATIK)
}

\author{
Oleh. Muh. Mu'ads Hasri \\ UIN Sunan Kalijaga Yogyakarta \\ e-mail: muazhas50@gmail.com
}

\begin{abstract}
Abtract
This article discusses about Qur'an opinion on the role of father in develoment of the child. The focus of this study is to reveal the verses of Qur'an that relate to the role of father in the family. Furthermore, this article will also illustrate the story of the father in the Qur'an. This article is a library research with descriptive-analytic method. The lens of contemporary and classic tafsir paradigm are also used as the aproach to analyse the data. Data collection is done thematically by gathering verses of the Qur'an in various surah that have correlations about the role of fathers. From the analysis that has been carried out, this research concludes several important remarks. Firts, the Qur'an shows a role that should be applied by a father in the development process of his children, one of which is by monitoring and controlling the daily lives of children, instilling educational values, building good closeness and communication with children, and providing support and direction well. Second, several verses in the Qur'an describe the role of fathers who have their own way of educating their children, so that the method is relevant to be applied in the present context, They are Luqman, Prophet Ibrahim, Prophet Nuh, and Prophet Ya'qub.
\end{abstract}

Keywords: Al-quran; Child development, Role of father.

\begin{abstract}
Abstrak
Artikel ini membahas tentang pandangan al-Qur'an terhadap peran ayah dalam proses perkembangan anak. Adapun yang menjadi fokus kajian dalam penelitian ini adalah mengupas ayat-ayat al-Qur'an yang berkaitan dengan peran ayah dalam keluarga. Selain itu, artikel ini juga akan menggambarkan kisah ayah dalam al-Qur'an. Artikel ini merupakan jenis penelitian pustaka. Metode yang digunakan dalam penelitian ini adalah deskriptif-analisis dengan menggunakan pendekatan paradigma tafsir klasik-kontemporer. Pengumpulan data dilakukan secara tematik, yaitu mengumpulkan ayat-ayat al-qur'an di berbagai surah yang memiliki korelasi tentang peran ayah. Dari analisis yang telah dilakukan, penelitian ini menyimpulkan bahwa: pertama, al-Qur'an menunjukkan peran yang seharusya diaplikasikan oleh seorang ayah dalam proses perkembangan anakanaknya, salah satunya dengan memantau dan mengontrol keseharian anak, menanamkan nilai-nilai pendidikan, membangun kedekatan dan komunikasi yang baik bersama anak, dan memberi dukungan serta arahan yang baik. Kedua, beberapa ayat dalam al-Qur'an menggambarkan peran ayah yang memiliki cara tersendiri dalam mendidik anaknya, sehingga cara tersebut relevan untuk diaplikasikan dalam konteks kekinian. Sosok ayah yang dimaksud adalah Luqman, Nabi Ibrahim, Nabi Nuh, dan Nabi Ya'qub.
\end{abstract}

Kata kunci: Al-Qur'an; Perkembangan anak; Peran ayah. 


\section{A. Pendahuluan}

Pemahaman masyarakat di zaman dulu adalah ibu lebih sering berada di rumah sebagai wujud dari pengasuhan untuk menjaga dan merawat anak sebagai implementasi dari pengasuhan untuk memenuhi nafkah batin anak. Sedangkan substansi perlindungan adalah ayah lebih sering di luar rumah mencari dan memenuhi nafkah lahir sebagai implementasi dari perlindungan. ${ }^{1}$ Sehingga kurang memperhatikan perkembangan serta psikologi anak. Padahal hal ini sangat penting bagi perkembangan anak ke depan. Namun pemahaman masyarakat seperti ini tidak dapat dinilai salah karna memang dalam ayat al-Qur'an surah alBaqarah: (233), terlihat jelas bahwa tanggungan nafkah yang diberikan kepada ayah memang cukup berat sehingga tidak heran jika ayah dominan berada di luar lingkungan keluarga.

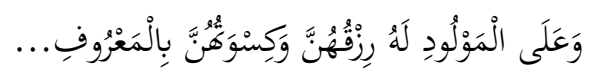

Terjemahnya: Dan kewajiban ayah memberi makan dan pakaian kepada para ibu dengan cara yang makruf... ${ }^{2}$

Pada ayat ini, al-Qur'an menegaskan bahwa tugas seorang ayah memberikan nafkah kepada istrinya. Menurut Abu Ja'far (w. $310 \mathrm{H})$ dalam tafsir At-Tabari mengatakan bahwa wajib bagi ayah untuk memberi makan isteri dan anak-anaknya, dengan makanan yang mengenyangkan serta pakaian dengan cara yang baik yang sesuai dengan kemampuannya. ${ }^{3}$ Dari sini dapat disimpulkan bahwa ayah memang memiliki tanggung jawab yang berat dalam keluarga, sehingga wajar jika ayah memperbanyak waktu di luar demi mencari nafkah bagi keluarganya.

Pemahaman yang kurang akan ayat di atas, maka akan menimbulkan permasalahan di tengah-tengah keluarga, salah satunya adalah kurangnya kontribusi seorang ayah dalam keluarganya, sehingga ayah hanya sekadar

1 Harmaini dkk., "Peran Ayah dalam Mendidik Anak", Jurnal Psikologi, Vol. 10, Desember 2014, h. 81. 57.

${ }^{2}$ Departemen Agama R.I, Al-Qur'an dan Tejemahnya, (Jakarta: CV. Bumirestu, 1990), h.

${ }^{3}$ Abu Ja'far Muhammad bin Jarī At-Tabari, Jāmi'ul Al-Bayān fi Ta'wil Al-Qur'ān Jilid 4, terj. Ahsan Askan, (Jakarta: Pustaka Azzam, 2008), h. 17. 
memberikan nafkah tanpa memikirkan betapa pentingnya kontribusi ayah dalam mendidik moral si anak, padahal bukan hanya itu peran seorang ayah dalam keluarga, terutama dalam hal mendidik, membina, dan menasehati anaknya. Ibarat sebuah kapal, ayah merupakan nahkoda yang akan menentukan arah berlayar keluarganya. Namun terkadang perannya tidak terlalu dirasakan oleh beberapa keluarga. Begitu juga dalam hal melindungi keluarga, ayah harus menjadi pelindung bagi keluarga, baik secara fisik maupun non-fisik. Selain itu, ayah juga harus memberikan kenyamanan dan keamanan emosional, serta bertanggung jawab atas finansial keluarga.

Umat Islam dalam perspektifnya menjadikan al-Qur'an sebagai pedoman hidup mereka. Karena dijadikan sebagai pedoman hidup, maka al-Qur'an patut dijadikan titik kembali dalam mencari solusi akan permasalahan-permasalahan sosial. Dalam al-Qur'an, terdapat beberapa ayat yang menceritakan tentang kisah seorang ayah dan anaknya, antara lain kisah Luqman al-Hakim; Nabi Ibrahim as.; Nabi Nuh as.; dan Nabi Ya'qub as. Sebagian besar dari ayat-ayat yang ditemukan menyinggung tentang relasi antara ayah dan anak, namun ayat yang menyinggung tentang hubungan ibu dan anak hanya pada satu tempat, yaitu kisah Nabi Isa dan ibunya. Melalui kisah-kisah ini, dapat ditemukan bahwa al-Qur'an secara tidak langsung memberikan isyarat bahwa ayah memiliki peran penting dalam proses perkembangan anak.

Berdasar pada permasalahan tersebut sebelumnya, maka penulis mengumpulkan ayat-ayat yang berkaitan dengan peran ayah, sehingga akan ditemukan pandangan al-Qur'an tentang peran ayah dalam proses perkembangan anak. Dikarenakan penelitian ini merupakan tematik konseptual maka pengumpulan data dalam penelitian ini adalah mencari data-data dari sumber primer (al-Qur'an dan hadis) maupun sekunder yang menjelaskan mengenai peran ayah dalam al-Qur'an dengan merujuk kepada buku-buku yang dipakai sebagai rujukan. Kemudian mencari penjelasan melalui pendapat-pendapat mufassir, hadis-hadis dan atau literatur-literatur lainnya yang berkaitan dengan tema pembahasan. 


\section{B. Ayat-Ayat Tentang Peran Ayah}

Adapun ayat-ayat al-Qur'an yang ditemukan berjumlah sekitar 6 ayat dan masing-masing merupakan kisah dan dialog antara ayah dan anaknya dalam alQur'an yang terdapat di beberapa surah. Jika diklasifikasikan maka sebagai berikut:

1. Dialog Nabi Ibrahim as. dan anak-anaknya, dalam:

a. QS. Al-Baqarah: (132);

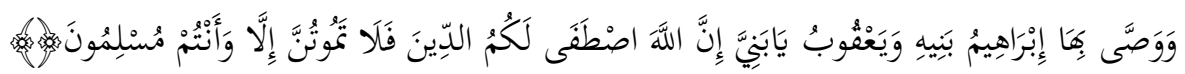

Terjemahnya: Dan Ibrahim telah mewasiatkan ucapan itu kepada anak-anaknya, demikian pula Ya'qub. (Ibrahim berkata): "hai anak-anakku! Sesungguhnya Allah telah memilih agama ini bagimu, maka janganlah kamu mati kecuali dalam memeluk agama Islam". ${ }^{4}$

b. QS. Al-Baqarah: (133),

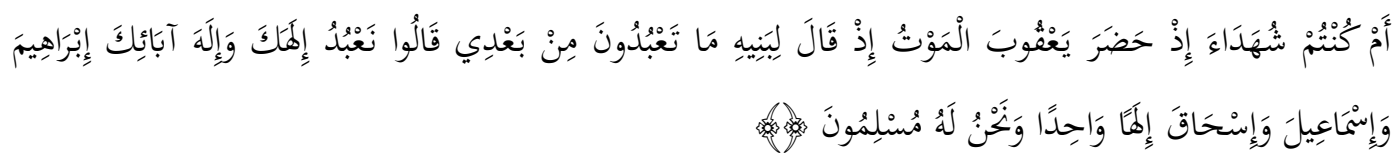

Terjemahnya: Adakah kamu hadir ketika Ya'qub kedatangan (tanda-tanda) maut, ketika ia berkata kepada anak-anaknya: " apa yang kamu sembah sepeninggalku ?" mereka menjawab: "kami akan menyembah Tuhanmu dan Tuhan nenek moyangmu, Ibrahim, Ismail dan Ishaq, (yaitu) Tuhan yang Maha Esa dan kami hanya tunduk patuh kepadaNya". 5

c. QS. As-Shaffat: (102),

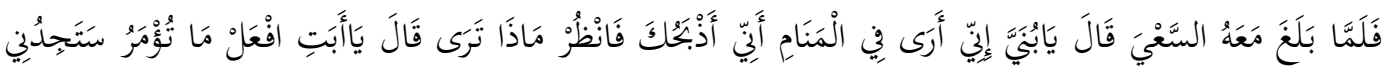

$$
\begin{aligned}
& \text { إِنْ شَاءَ اللَّهُ مِنَ الصَّابِرِينَ }
\end{aligned}
$$

Terjemahnya: Maka tatkala anak itu sampai (pada umur) sanggup berusaha bersama-sama Ibrahim, Ibrahim berkata: "hai anakku, sesungguhnya aku melihat dalam mimpi bahwa aku menyembelihmu. Maka pikirkanlah apa pendapatmu" ia menjawab: "hai bapakku, kerjakanlah apa yang diperintahkan kepadamu, insyaAllah kamu akan mendapatiku termasuk orang-orang yang sabar". ${ }^{6}$

\footnotetext{
${ }^{4}$ Departemen Agama R.I, Al-Qur'an dan Tejemahnya..., h. 34.

${ }^{5}$ Departemen Agama R.I, Al-Qur'an dan Tejemahnya ..., h. 34.

${ }^{6}$ Departemen Agama R.I, Al-Qur'an dan Tejemahnya ..., h. 725.
} 
2. Dialog Nabi Nuh as. dan anaknya dalam QS. Hud: (42);

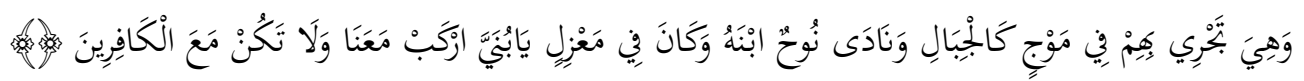

Terjemahnya: Dan bahtera itu berlayar membawa mereka dalam gelombang laksana gunung. Dan Nuh memanggil anaknya, sedang anak itu berada di tempat yang jauh terpencil: "hai anakku, naiklah (ke kapal) bersama kami dan janganlah kamu berada bersama orang-orang yang kafir". 7

3. Dialog Nabi Ya'qub as. dan anaknya dalam QS. Yusuf: (4-5);

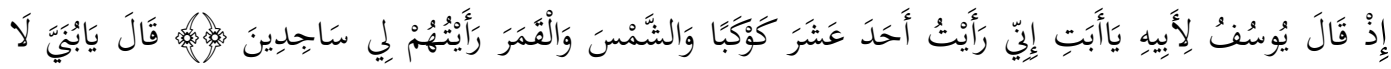

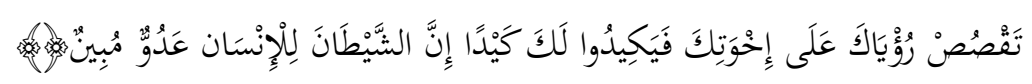

Terjemahnya: Ketika Yūsuf berkata kepada ayahnya (Ya'qūb): “wahai ayahku, sesungguhnya aku bermimpi melihat sebelas bintang, matahari dan bulan, kulihat semuanya bersujud kepadaku". Ayahnya (Ya'qūb) berkata: "hai anakku, janganlah kamu ceritakan mimpi-mimpimu itu kepada saudara-saudaramu, maka mereka membuat makar (untuk membinasakan) mu. Sesungguhnya syaițan itu adalah musuh yang nyata bagi manusia.". 8

4. Dialog Luqman al-Hakim dan anaknya dalam:

a. QS. Luqman: (13);

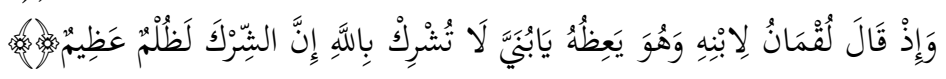

Terjemahnya: Dan ingatlah ketika Luqman berkata kepada anaknya, di waktu ia memberi pelajaran kepadanya: "Hai anakku, janganlah kamu mempersekutukan Allah, sesungguhnya mempersekutukan Allah adalah benar-benar kezaliman yang besar". ${ }^{9}$

b. QS. Luqman: (16),

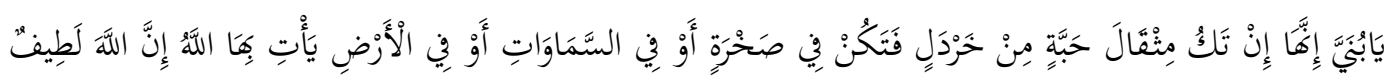

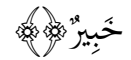

Terjemahnya: Hai anakku, sesungguhnya jika ada (sesuatu perbuatan) seberat biji sawi , dan berada dalam batu atau di langit atau di dalam bumi, niscaya Allah akan mendatangkannya (mebalasanya). Sesungguhnya Allah Maha Halus Lagi Maha Mengetahui. ${ }^{10}$

\footnotetext{
${ }^{7}$ Departemen Agama R.I, Al-Qur'an dan Tejemahnya ..., h. 333.

${ }^{8}$ Departemen Agama R.I, Al-Qur'an dan Tejemahnya ..., h. 348.

${ }^{9}$ Departemen Agama R.I, Al-Qur'an dan Tejemahnya ..., h. 654.

${ }^{10}$ Departemen Agama R.I, Al-Qur'an dan Tejemahnya ..., h. 655
} 
c. QS. Luqman: (17),

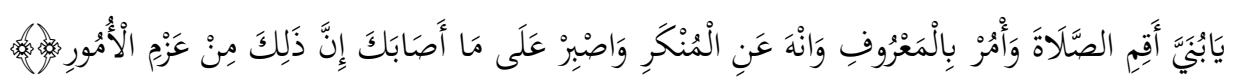

Terjemahnya: Hai anakku, dirikanlah Salat dan suruhlah (manusia) mengerjakan yang baik dan cegahlah (mereka) dari perbuatan yang mungkar dan bersabarlah terhadap apa yang menimpa kamu. Sesungguhnya yang demikian itu termasuk hal-hal yang diwajibkan. ${ }^{11}$

Dari beberapa ayat di atas menunjukkan bahwa ayah ternyata terlibat langsung dalam proses perkembangan anaknya, terlihat dari kisah-kisah ayah dan anak yang digambarkan oleh al-Qur'an. Ayah yang selalu mendoakan anaknya, ayah yang sangat akrab dengan anaknya, ayah yang selalu menasehati dan mengajari anaknya, semuanya tergambar jelas dalam makna ayat-ayat tersebut, yang selanjutnya akan dibahas satu persatu.

\section{Peran Ayah dalam Proses Perkembangan Anak Perspektif Al-Qur'an}

1. Sebagai Pendidik dan Pembentuk Kepribadian Anak-anaknya

Merupakan suatu tanggung jawab seorang ayah untuk selalu memberi nasehat kepada anak-anaknya. Al-Qur'an surah Luqman (31): 13 sebagai berikut:

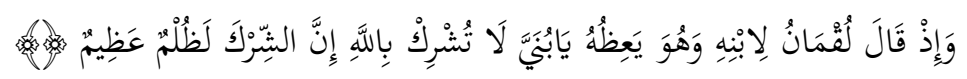

Terjemahnya: Dan ingatlah ketika Luqman berkata kepada anaknya, di waktu ia memberi pelajaran kepadanya: "Hai anakku, janganlah kamu mempersekutukan Allah, sesungguhnya mempersekutukan Allah adalah benar-benar kezaliman yang besar". ${ }^{12}$

Menurut Quraish Shihab dalam tafsirnya, kata يعظه ya 'izuhū terambil dari kata و و wa'za yaitu nasehat berbagai kebajikan dengan cara yang menyentuh hati. Kata ini juga mengisyaratkan bahwa nasehat itu dilakukannya dari saat ke saat, sebagaimana yang dipahami dari bentuk kata kerja masa kini dan datang pada kata يعظ ya'izuh $\bar{u}^{13}$ Luqman dalam ayat ini menegaskan kepada anaknya agar tidak menyekutukan Allah Swt. karena hal itu merupakan kezaliman yang besar. Begitupun di ayat selanjutnya (16-19) berisi nasehat-nasehat luqman kepada anaknya.

\footnotetext{
${ }^{11}$ Departemen Agama R.I, Al-Qur'an dan Tejemahnya ..., h. 655.

${ }^{12}$ Departemen Agama R.I, Al-Qur'an dan Tejemahnya ..., h. 654.

${ }^{13}$ M.Quraish Shihab, Tafsir Al-Misbah: Pesan, Kesan dan Keserasian Al-Qur'an Vol. 11, (Jakarta: Gema Insani Press, 2002), h. 126.
} 
Begitu juga dengan kisah Nabi Nuh as. ketika memberi nasehat kepada anaknya dalam Surah Hud: (42) sebagai berikut:

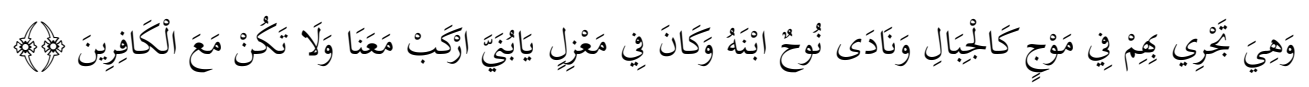

Terjemahnya: Dan bahtera itu berlayar membawa mereka dalam gelombang laksana gunung. Dan Nuh memanggil anaknya, sedang anak itu berada di tempat yang jauh terpencil: "hai anakku, naiklah (ke kapal) bersama kami dan janganlah kamu berada bersama orang-orang yang kafir". ${ }^{14}$

Dua ayat di atas menggunakan kata "ya bunayya" wahai anakku sayang. Luqman al-Hakim maupun Nabi Nuh as. menggunakan kata tersebut. Menurut Quraish Shihab, kata بنيّ adalah patron yang menggambarkan kemungilan. Kata بdalah bentuk tasgh̄̄r/perkecilan dari kata ابنيّ yang berarti anakku. Bentuk itu antara lain digunakan untuk menggambarkan kasih sayang, karena kasih sayang biasanya tercurah kepada anak. ${ }^{15}$ Berbeda dengan Al-Qurthubi, menurutnya bahwa lafaz بنيّ sendiri bukan bentuk hakikat tashgir, sekalipun lafaznya tashgir, namun merupakan bentuk tarqiq (ungkapan kelembutan dan kasih sayang), misalnya kalimat yang diungkapkan kepada seseorang Dari sini dapat diketahui bahwa dalam memberi nasehat baiknya disertai dengan penuh kasih sayang. Begitupun dengan ayat (31:16) dan (31:17), semuanya menggunakan kata dalam memberikan nasehat.

Nasehat-nasehat Luqman al-Hakim berisi tentang akhlak yang mulia di antaranya adalah larangan menyekutukan Allah Swt. (31:16). Kemudian Luqman melanjutkan nasehatnya berupa nasehat yang berkaitan dengan amal shaleh yang puncaknya adalah salat, dan amal kebaikan yang tercermin dalam amar ma'ruf nahi munkar serta membentengi diri dari kegagalan (31:17). Nasehat tentang adab ketika berbicara (31:18). Nasehat untuk tetap tawadu' atau rendah hati (31:19).

Adapun nasehat Nabi Nuh as. yang berisi nasehat-nasehat untuk menjauhi orang-orang kafir dan juga demi keselamatan anaknya meskipun anaknya disebutkan dalam tafsir merupakan anak durhaka, namun dengan penuh rasa kasih

\footnotetext{
${ }^{14}$ Departemen Agama R.I, Al-Qur'an dan Tejemahnya ..., h. 333.

${ }^{15}$ M.Quraish Shihab, Tafsir Al-Misbah; Vol. 13,... h. 127.

${ }^{16}$ Syaikh Imam Al-Qurthubi, Tafsir Al-Qurthubi Jilid 14, terj. Marwan Affandi dkk., (Jakarta: Pustaka Azzam, 2009), h. 152.
} 
sayang Nabi Nuh as. tetap ingin menyelamatkan anaknya. Beliau saat itu masih dapat menasehati dan membujuk anaknya sebelum tenggelam. Nasehat yang penuh dengan kasih sayang, namun anaknya tetap keras kepala dan menolak untuk mengikuti ayahnya yaitu Nabi Nuh as.

Tidak berhenti sampai di situ, al-Qur'an sekali lagi menunjukkan sosok seorang ayah yang tak henti-hentinya memberi nasehat kepada anak-anaknya yaitu Nabi Ibrahim as. sosok ayah yang tangguh dan tinggi rasa khawatirnya terhadap anak-anaknya. Dapat dilihat dalam surah al-Baqarah: (132) sebagai berikut:

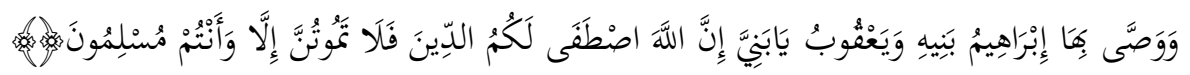

Terjemahnya: Dan Ibrahim telah mewasiatkan ucapan itu kepada anak-anaknya, demikian pula Ya'qub. (Ibrahim berkata): "hai anak-anakku! Sesungguhnya Allah telah memilih agama ini bagimu, maka janganlah kamu mati kecuali dalam memeluk agama Islam". ${ }^{17}$

Ayat ini menggambarkan arti penting peran ayah bahwa seorang ayah selalu memberi arahan terhadap anak-anaknya. Ibnu Katsir menjelaskan "hai anak-anakku! Sesungguhnya Allah telah memilih agama ini bagimu, maka janganlah kamu mati kecuali dalam memeluk agama Islam" berarti berbuat baiklah kamu dalam kehidupan dan tetap teguhlah dalam agama ini, niscaya Allah Swt. akan menganugrahimu kematian dalam kondisi demikian, sebab seseorang biasanya meninggal dalam kondisi tengah dilakukannya, dan dibangkitkan dalam kondisi itu pula.

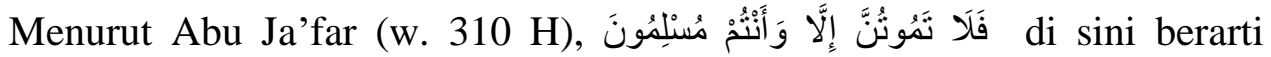
janganlah kalian memisahkan diri dari agama ini dalam kehidupan kalian, yaitu Islam, sebab tidak seorangpun yang dapat mengetahui kapan ajalnya akan

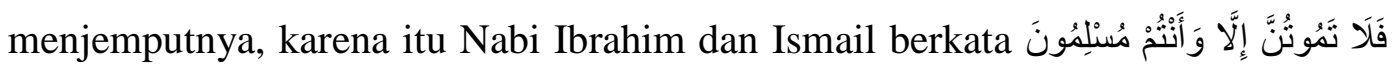
karena kalian tidak tahu kapan ajal akan datang kepada kalian, siang hari atau malam hari. ${ }^{18}$ Faktor yang menjadikan beliau mendapatkan kedudukan yang tinggi di sisi Allah Swt. serta ajaran yang dianut oleh beliau kemudian diteruskan

\footnotetext{
${ }^{17}$ Departemen Agama R.I, Al-Qur'an dan Tejemahnya ..., h. 34.

${ }^{18}$ Abu Ja'far Muhammad Bin Jarīr At-Tabari, Jāmi'u Al-Bayān fi Ta'wĭl Al-Qur'ān Jilid 2, terj. Ahsan Askan, (Jakarta: Pustaka Azzam, 2008), h. 556.
} 
kepada generasi setelahnya. Inilah yang diuraikan oleh ayat ini dengan firmanNya: dan Ibrahim telah mewasiatkannya yaitu agama, atau prinsip ajaran itu kepada anak-anaknya, yaitu Ismail, Ishaq dan saudara-saudara mereka. ${ }^{19}$

Begitu juga dengan Nabi Muhammad Saw. ketika memberi nasehat kepada anak asuhnya Umar bin Abdullah dalam hadis riwayat Muslim No. 5376:

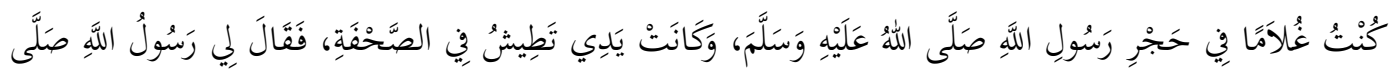

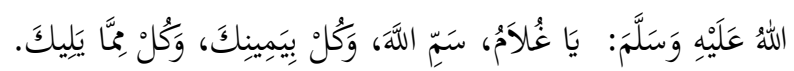

Artinya: Sewaktu aku masih kecil, saat berada dalam asuhan Rasulullah Saw. pernah suatu ketika tanganku ke sana kemari (saat mengambil makanan) di nampan. Lalu Rasulullaah Shalla Allahu 'alaihi wa sallam berkata kepadaku: "Wahai bocah, ucaplah bismillah dan makanlah dengan tanganmu, serta ambil makanan yang berada di dekatmu". ${ }^{20}$

Dari beberapa dalil diatas menunjukkan bahwa peran ayah sangatlah penting dalam memberi nasehat, arahan, dan petunjuk kepada anak-anaknya. Tidak hanya itu namun ketika menjalankannya haruslah dibarengi dengan rasa kasih sayang, sebab dengan kasih sayang maka anak dapat mencerna dengan baik makna dari isi nasehat-nasehat yang diberikannya.

2. Membangun Kebersamaan dengan Anak

Peran selanjutnya adalah membangun kebersamaan bersama anak. Ayah merupakan salah satu model yang diperlukan oleh si anak ketika dibutuhkan. Karena tidak selalu dalam kehidupan anak dipenuhi dengan keterlibatan ibu, ayah juga berperan penting untuk bersama-sama dengan anaknya, seperti jalan bersama, dan mendengarkan curahan hati si anak. Dalam al-Qur'an surah asShaffat: (102) digambarkan kisah Nabi Ibrahim dan anaknya sebagai berikut:

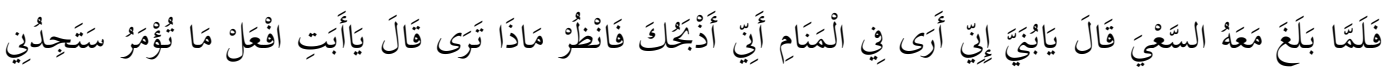

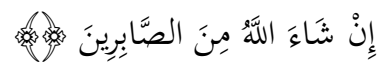

Terjemahnya: Maka tatkala anak itu sampai (pada umur) sanggup berusaha bersama-sama Ibrahim, Ibrahim berkata: "hai anakku, sesungguhnya aku melihat dalam mimpi bahwa aku menyembelihmu. Maka pikirkanlah apa pendapatmu" ia menjawab: "hai bapakku,

\footnotetext{
${ }^{19}$ M.Quraish Shihab, Tafsir Al-Misbah: Vol. 1,..h. 330.

${ }^{20}$ Imam Muslim, Shah̄̄h Muslim Juz 13, (Beirut: Dar Al-Marefah, 2007), h. 268.
} 
kerjakanlah apa yang diperintahkan kepadamu, insyaAllah kamu akan mendapatiku termasuk orang-orang yang sabar". ${ }^{21}$

Ayat ini menggambarkan kisah Nabi Ibrahim bersama anaknya ketika saling bincang. Ibnu Katsir sebagaimana yang dikutip dalam buku Ringkasan Tafsir Ibnu Katsir menjelaskan firman Allah Swt. "Maka tatkala anak itu sampai (pada umur) sanggup berusaha bersama-sama Ibrahim”, yaitu menjadi besar dan dewasa serta dapat pergi bersama ayahnya dan sanggup melaksanakan pekerjaan yang dikerjakan oleh ayahnya. ${ }^{22}$ Selanjutnya Sayyid Qutb menjelaskan bahwa kalimat itu berarti Ibrahim merasakan kenikmatan terhadap anaknya, menyertai perjalanannya dan menemaninya dalam kehidupannya. ${ }^{23}$

فلما بلغ مegitu juga dengan Al-Maraghi dalam tafsirnya menjelaskan kata معه السعي diartikan tatkala Ismail mencapai umur yang ia dapat membantu ayahnya untuk berusaha bersama-sama dengan beliau dalam pekerjaan-pekerjaan dan memenuhi kebutuhan-kebutuhan hidupnya. ${ }^{24}$ Menurut Al-Farra' (w. 207 H), bahwa Ismail ketika itu berumur 13 tahun. ${ }^{25}$ Dan sekali lagi Nabi Ibrahim memanggil anaknya dengan kata bunayya yang menurut Quraish Shihab kata

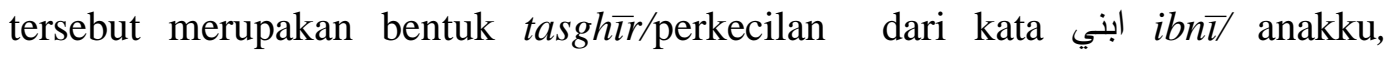
digunakan untuk menggambarkan kasih sayang, karena kasih sayang biasanya tecurah kepada anak. Ini mengisyaratkan bahwa beliau sangat sayang kepada anaknya, dengan selalu berada disamping anaknya ketika diperlukan, karena anak butuh seorang ayah di sampingnya.

Begitu juga juga dengan kisah Nabi Ya'qub dan anaknya dalam surah Yusuf: (4-5) yaitu kedekatan Nabi Ya'qub dengan anaknya, dimana seorang ayah

${ }^{21}$ Departemen Agama R.I, Al-Qur'an dan Tejemahnya ..., h. 725.

${ }^{22}$ Muhammad Nasib Ar-Rifa'i, Ringkasan Tafsir Ibnu Katsir Jilid 4 terj. Syihabuddin (jakarta: Gema Insani Press, 2012), h. 30.

${ }^{23}$ Sayyid Qutb, Tafs̄̄r Fi Zilālil Qur'ān Jilid 6, terj. As'ad Yasin dkk., (Jakarta: Gema Insani Press, 2003), h. 346.

${ }^{24}$ Ahmad Mustafa Al-Maragi, Tafsir Al-Marāgiy juz, 22, terj. Bahrun Abubakar dkk., (Semarang: Toha Putra, 1989), h, 127.

${ }^{25}$ Syaikh Imam Al-Qurthubi, Tafsir Al-Qurthubi Jilid 15, terj. Marwan Affandi dkk., (Jakarta: Pustaka Azzam, 2009), h. 234. 
menjadi tempat mengadu sang anak ketika dilanda rasa bingung akan mimpinya. Berikut firman-Nya:

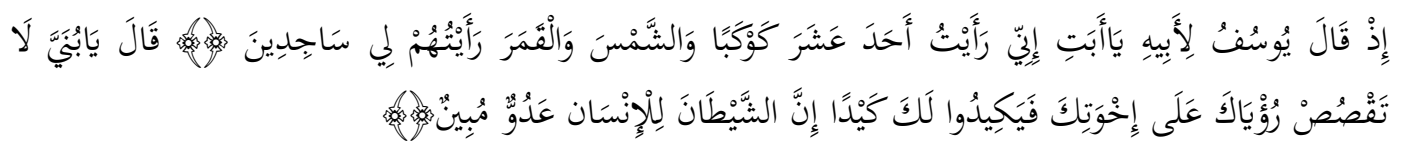

Terjemahnya: Ketika Yusuf berkata kepada ayahnya (Ya'qub): "wahai ayahku, sesungguhnya aku bermimpi melihat sebelas bintang, matahari dan bulan, kulihat semuanya bersujud kepadaku". Ayahnya (Ya'qub) berkata: "hai anakku, janganlah kamu ceritakan mimpi-mimpimu itu kepada saudara-saudaramu, maka mereka membuat makar (untuk membinasakan) mu. Sesungguhnya syaițan itu adalah musuh yang nyata bagi manusia.". ${ }^{26}$

Ayat ini menggambarkan tentang kisah Nabi Ya'qub dan anaknya yaitu Nabi Yusuf yang ketika menceritakan mimpinya kepada ayahnya. Sungguh apa yang disampaikan itu adalah suatu hal yang sangat besar, apalagi bagi seorang anak yang sejak kecil hatinya diliputi oleh kesucian dan kasih sayang ayah. Kasih sayang ayahnya disambut pula dengan menghormati beliau, terlihat ketika beliau memanggil ayahnya dengan panggilan يا أبت, dia menggambarkan kedekatannya kepada beliau. Kedekatannya kepada ayahnya diakui oleh ayat ini, sehingga bukan nama ayahnya yang disebut oleh ayat ini, tetapi kedudukannya sebagai orang tua. Dengan penuh kasih sayang, sang ayah berkata, Hai anakku, janganlah kaти ceritakan mimpi-mimpimu itu kepada saudara-saudaramu.

ابني بata bunaya adalah bentuk tasghīr/perkecilan dari kata $i b n \bar{r} / a n a k k u$. Bentuk itu antara lain digunakan untuk menggambarkan kasih sayang, karena kasih sayang biasanya terurah kepada anak, apalagi yang masih kecil. Kesalahan-kesalahannya pun ditoleransi, paling tidak atas dasar dia dinilai masih kecil. ${ }^{27}$ Menurut Al-Qurthubi bahwa lafaz بنيّ sendiri bukan bentuk hakikat tashgir, sekalipun lafaznya tashgir, namun merupakan bentuk tarqiq (ungkapan kelembutan dan kasih sayang). ${ }^{28}$

\footnotetext{
${ }^{26}$ Departemen Agama R.I, Al-Qur'an dan Tejemahnya ..., h. 348.

${ }^{27}$ M.Quraish Shihab, Tafsir Al-Misbah: Vol. 11,.., h. 396.

${ }^{28}$ Syaikh Imam Al-Qurthubi, Tafsir Al-Qurthubi Jilid 14, terj. Marwan Affandi dkk...., h. 152.
} 
Ayat-ayat di atas menunjukkan kedekatan ayah dan anak. Ayah seharusnya selalu bersama dengan anaknya, selalu mendampingi anaknya, dapat dilihat dari kisah Nabi Ibrahim dan Ismail. Begitu juga dengan Nabi Ya'qub dan Nabi Yusuf, yang mana sang anak justru menyampaikan isi mimpinya kepada ayahnya tidak ke ibunya. Hal ini juga mengisyaratkan bahwa keberhasilannya dalam mendidik anak-anaknya.

3. Sebagai Pelindung dan Pengayom

Secara tegas al-Qur'an menegaskan kepada pemimpin keluarga agar bertanggung jawab penuh atas keluarganya, dalam surah at-Tahrim: (6) sebagai berikut:

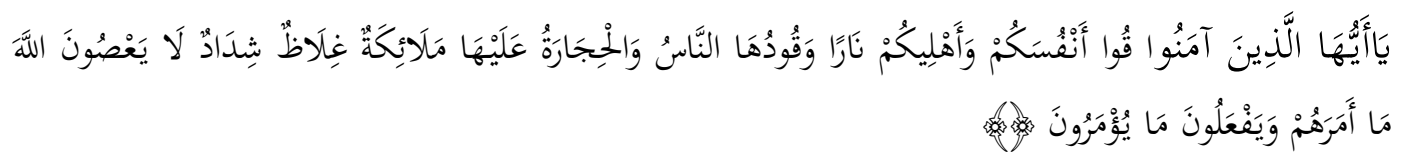

Terjemahnya: Hai orang-orang yang beriman, peliharalah dirimu dan keluargamu dari api neraka yang bahan bakarnya adalah manusia dan batu, penjaga malaikat yang kasar, keras, dan tidak mendurhakai Allah terhadap apa yang diperintahkan-Nya kepada mereka dan selalu mengerjakan apa yang diperintahkan. ${ }^{29}$

Ayat ini menyerukan bahwa salah satu tanggung jawab ayah sebagai pemimpin keluarga adalah untuk menjaga dan melindungi keluarganya, dengan cara tidak menyekutukan Allah Swt. dan selalu mengerjakan perintah-perintah Allah Swt. Beban tanggung jawab yang ada dalam dirinya dan keluarganya merupakan beban yang sangat berat dan menakutkan. Sebab neraka telah menantinya di sana, dan dia beserta keluarganya terancam dengannya. Maka merupakan kewajibannya membentengi dirinya dan keluarganya dari neraka yang selalu mengintai dan menantinya. ${ }^{30}$

Tanggung jawab seorang ayah sangatlah besar terhadap anak-anaknya. Dari awal lahir sang anak maka telah dimulai tanggung jawab yang besar itu, karena anak lahir dalam keadaan fitrah, sehingga orangtua yang menentukan benar atau tidaknya anak itu kelak. Hal ini dijelaskan Rasulullah Saw. dalam hadis riwayat al-Bukhari No. 1359 sebagai berikut:

\footnotetext{
${ }^{29}$ Departemen Agama R.I, Al-Qur'an dan Tejemahnya ..., h. 951.

${ }^{30}$ Sayyid Qutb, Tafsīr Fi Zilālil Qur'ān Jilid 11, terj. As'ad Yasin dkk...., h. 338.
} 


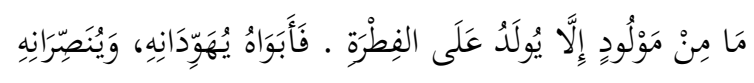

Artinya: Tiada seorangpun yang dilahirkan kecuali dilahirkan pada fitrahnya. Kedua orang tuanyalah yang menjadikannya Yahudi, Nasrani atau Majusi. $^{31}$

Hadis ini menunjukkan bahwa orang tua bertanggung jawab atas shaleh atau tidaknya anak, karena pada awalnya anak berada pada fitrahnya, kemudian datanglah pengaruh-pengaruh luar, termasuk benar atau tidaknya orang tuanya. Tidak hanya bertanggung jawab atas dunianya, namun juga di akhirat, karena jika sang anak tersesat di jalan yang tidak lurus maka ayah akan mendapat ganjaran di akhirat karena perbuatan anaknya, sebagaimana hadis Rasulullah Saw. dalam riwayat Muslim No. 1829:

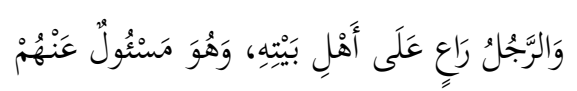

Artinya: Seorang laki-laki (ayah) adalah pemimpin bagi keluarganya, dan dia bertanggung jawab atas mereka semua. ${ }^{32}$

Berdasar pada hadis di atas, merupakan suatu tanggung jawab bagi ayah untuk membimbing istri dan anaknya di jalan yang benar. Jadi sebagai ayah harus lebih meningkatkan perannya dalam membina keluarga terutama agamanya meskipun telah hampir tiba ajalnya, seperti kisah dalam al-Qur'an surah alBaqarah (2): 133 menggambarkan Nabi Ibrahim sebagai berikut:

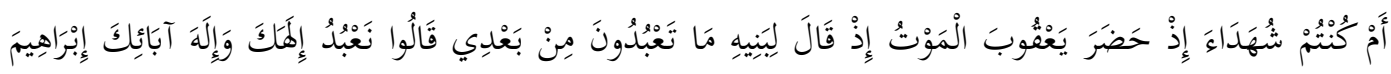

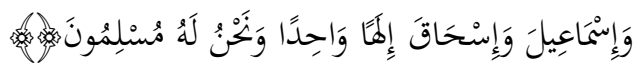

Terjemahnya: Adakah kamu hadir ketika Ya'qub kedatangan (tanda-tanda) maut, ketika ia berkata kepada anak-anaknya: "apa yang kamu sembah sepeninggalku?" mereka menjawab: "kami akan menyembah Tuhanmu dan Tuhan nenek moyangmu, Ibrahim, Ismail dan Ishaq, (yaitu) Tuhan yang Maha Esa dan kami hanya tunduk patuh kepadaNya". ${ }^{33}$

${ }^{31}$ Al-Imām Al-Bukhāri, Shaḥ̣̄h Al-Bukhāri Jilid 1, (Beirut: Dar Al-Kotob Al-Ilmiyah, 2009), h. 330.

${ }^{32}$ Imām Muslim Al-Hajjāj, Shah̄̄h Muslim Jilid 3, (Beirut: Dar Al-Kotob Al-Ilmiyah, 2008), h. 225.

${ }^{33}$ Departemen Agama R.I, Al-Qur'an dan Tejemahnya ..., h. 34. 
Menurut Sayyid Qutb, ayat ini menggambarkan pemandangan ketika Nabi Ya'qub bersama anak-anaknya saat beliau menghadapi kematiannya. Sakaratul maut yang sudah di depan mata namun masih ada yang mengusik hati beliau, masih ada yang menyibukkan hati beliau, yaitu amanat, modal, dan warisan yang hendak ingin disampaikannya. Sehingga beliau mengeluarkan sebuah kalimat kepada anak-anaknya "apakah yang kamu sembah sepeninggalku ?". tergambar jelas bentuk tanggung jawab yang sangat besar yang dipikul oleh Nabi Ibrahim sebagai ayah dari anak-anaknya. ${ }^{34}$ Kisah tersebut menunjukkan betapa khawatirnya Nabi Ibrahim kepada anak-anaknya. Hal ini terlihat jelas ketika beliau hendak menemui ajalnya namun masih tetap khawatir akan kehidupan anak-anaknya.

Sosok ayah yang sangat patut untuk dijadikan sebagai contoh yang baik terhadap perkembangan anak. Demikianlah penjelasan al-Qur'an tentang peran ayah. Tak dapat dipungkiri bahwa ayah sangat berperan dalam proses perkembangan anak.

\section{Penutup}

Ayah merupakan kepala keluarga yang harus dijadikan panutan bagi anakanaknya dan bertanggung jawab penuh atasnya. Oleh karena itu, peran ayah dalam keluarga meliputi membangun kebersamaan dan komunikasi yang baik dengan anak; sebagai pengontrol dan pemantau keseharian anak; senantiasa menanamkan nilai-nilai pendidikan kepada anak; serta memberikan dukungan serta arahan. Dalam al-Qur'an sendiri, terdapat beberapa ayat dalam al-Qur'an yang menggambarkan peran ayah dalam mendidik anaknya, sehingga cara tersebut relevan untuk diaplikasikan dalam konteks kekinian. Sosok ayah yang dimaksud adalah Luqman, Nabi Ibrahim, Nabi Nuh, dan Nabi Ya'qub. Selain dari pada itu, al-Qur'an juga menunjukkan peran yang seharusya diaplikasikan oleh seorang ayah dalam proses perkembangan anak-anaknya, salah satunya dengan memantau dan mengontrol keseharian anak, menanamkan nilai-nilai pendidikan, membangun kedekatan dan komunikasi yang baik bersama anak, memberi dukungan serta arahan yang baik, dan melindungi dan mengayomi anak-anaknya.

\footnotetext{
${ }^{34}$ Sayyid Qutb, Tafs̄̄r Fi Zilālil Qur'ān Jilid 1, terj. As'ad Yasin dkk...., h. 142
} 


\section{Daftar Pustaka}

Departemen Agama RI, Al-Qur'an dan Terjemahnya, Jakarta: CV. Bumirestu, 1990.

Harmaini (dkk), "Peran Ayah dalam Mendidik Anak", Jurnal Psikologi: Vol. 10. Desember 2014.

Al-Imam Al-Bukhari, Shaḥih Al-Bukhari, Jilid 1; Beirut: Dar Al-Kotob AlIlmiyah, 2009.

Al-Imam Muslim, Shahih Muslim, Jilid 3; Beirut: Dar Al-Kotob Al-Ilmiyah, 2008.

Al-Maragiy, Ahmad Mustafa, Tafsir Al-Maragiy, Juz 2-22; terj. Bahrun Abu Bakar (dkk). Semarang: Toha Putra, 1989.

Al-Qurthubi, Tafsir Al-Qurthubi, Jilid 14-15; Terj. Marwan Affandi dkk. Jakarta: Pustaka Azzam, 2009.

Qutb, Sayyid. Tafsir Fi Zilalil Qur'an, Jilid 1-6-11; Terj. As'ad Yasin (dkk) di Bawah Naungan Al-Qur'an, Jakarta: Gema Insani, 2003.

Ar-Rifa'i, Muhammad Nasi, Ringkasan Tafsir Ibnu Katsir, Jilid 1-4; Terj. Syihabuddin. Jakarta: Gema Insani, 2012.

Shihab, M.Quraish. Tafsir Al-Misbah: Pesan, Kesan dan Keserasian Al-Qur'an, Vol. 1-11-13; Jakarta: Gema Insani, 2002.

At-Tabari, Muhammad Bin Jar̄ir, Jami'ul Al-Bayan fi Ta'wil Al-Qur'an; Jilid 24-20; Terj. Ahsan Askan. Jakarta: Pustaka Azzam, 2008. 